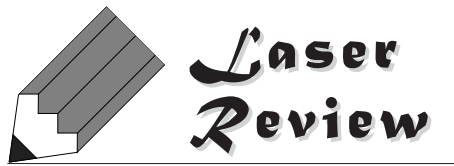

\author{
脳内光伝播のシミュレーション \\ 岡田 英史 \\ 慶應義塾大学 理工学部電子工学科 ( ₹223-8522 神奈川県横浜市港北区日吉3-14-1)
}

\section{Forward Modelling of Light Propagation in a Brain}

\author{
Eiji OKADA \\ Department of Electronics and Electrical Engineering, Faculty of Science and Technology, Keio University, \\ 3-14-1 Hiyoshi, Kohoku-ku, Yokohama, Kanagawa 223-8522
}

(Received April 30, 2002)

\begin{abstract}
Near infrared spectroscopy and imaging have been applied to measure brain activities. The light scattering in the tissue causes ambiguity in the volume of tissue sampled with a source-detector pair of near infrared instruments and hence theoretical modelling to obtain light propagation in the head is very important for the brain activity measurements. In this paper two theoretical methods, Monte Carlo simulation and hybrid Monte Carlodiffusion method, for calculation of light propagation in the brain are reviewed. The light propagation in the brain is strongly affected by the heterogeneity of tissue, especially the presence of low scattering cerebrospinal fluid (CSF). The results indicate that the presence of the CSF layer improves the sensitivity of the optical signal to brain activities.
\end{abstract}

Key Words: Near infrared spectroscopy, Near infrared imaging, Monte Carlo simulation, Diffusion equation, Brain activity

\section{1.はじめに}

近赤外光は生体組織に対して比較的高い透過性をも ち，近赤外光を頭皮に照射すると，その一部は脳組織ま で到達した後に再び体表まで戻ってくる。脳が活動する と, その部位の血液量や酸素状態が変化するため, 脳組 織の吸収が部分的に変化する。脳組織の吸収変化によっ て, 体表へ戻ってくる近赤外光の光量が変化するため, この変化を捉えることによって脳の活動状態を測定する ことができる.さらに頭部に複数の入射一検出ファイバ 対を配置して多点計測を抄こなった結果から，脳機能を 断層画像1-3) やトポグラフィー画像4,5) として再構築するこ とも扮こなわれている.

光を用いた生体計測に共通する最大の問題点は, 生体 組織が強い散乱を有する媒質であるということである。 脳機能計測の場合においても, 近赤外光は頭部組織内を 多重散乱を受けながら伝播するため, 検出光の伝播経路 は組織内に広く分布している。ささらに, 頭部組織は頭 皮, 頭蓋骨, 脳などの複数の組織からなる不均質な構造 をもって扔り，このことが脳組織内の光伝播に影響を及 ぼしている. 生体組織内に扔ける光伝播の状態を実測に よって求めることは現在の技術では不可能であることか ら, 頭部組織内に扔ける散乱現象を理論解析して, 光伝 播をシミュレーションすることが必要不可欠となる。本
稿では, 近赤外光を用いた脳機能計測のための, 頭部組 織の非均質性を考慮した脳内光伝播シミュレーションの 方法として, モンテカルロ・シミュレーション, 㧍よび 光拡散方程式とモンテカルロ・シミュレーションのハイ ブリッド法について紹介する.

\section{2. なぜ光伝播シミュレーションが必要か}

光を用いた脳機能計測では, 頭部に近赤外光を入射, 検出する光ファイバ対を装着して, 検出光の減光度変化 を測定する。脳が活動すると, 脳組織の血液量や酸素状 態が部分的に変化する。このとき, 酸化・還元へモグロ ビン等による組織の吸収が変化するため, このことに起 因する検出光の強度変化を捉えることで脳機能を測定す ることができる，仮に，頭部組織が均質で吸収変化が一 様に生じるものとすると, 検出光の減光度変化 $\triangle O D$ と組 織の吸収係数の変化 $\Delta \mu_{a}$ の間には, 次式で表されるModified Beer-Lambert則が成立することになる6)。

$$
\Delta O D=\ln \left(I_{0} / I\right)=\Delta \mu_{a}<L>
$$

ここで, $I_{0}, I$ は脳の活動前後における検出光強度, $\langle L>$ は 検出光が組織内を伝播した距離の平均であり, 平均実効 光路長と呼ばれている。平均実効光路長は，パルスレー ザーとストリーク・スコープを利用した時間分解計測を 
おこなうことで実測が可能である。

しかし, 実際の頭部は複数の組織からなる不均質構造 をしている。そこで, 頭部組織を頭皮(scalp), 頭蓋骨 (skull), 脳脊髄液層 (cerebrospinal fluid: CSF), 脳組織 (brain)のように個々の組織に分けて考えると, 平均実効 光路長は式(2)のように, 検出光が各組織内を伝播した平 均距離である部分実効光路長の和として与えられる7).

$<L>=<L_{\text {scalp }}>+<L_{\text {skull }}>+<L_{\text {CSF }}>+<L_{\text {brain }}>$

もし, 脳が活動する前後における組織内の血液量や酸素 状態が, 脳組織の中だけで変化しているものと仮定する と, 式(1)は以下のように書き換えることができる8).

$$
\Delta O D=\Delta \mu_{\text {abrain }}<L_{\text {brain }}>
$$

ここで, $\Delta \mu_{a \text { brain }}$ は脳組織で生じた吸収変化, $<L_{\text {brain }}>$ は脳 組織における部分実効光路長である. 式(3)からも明らか なように，脳組織における部分実効光路長が長いという ことは, 脳組織での吸収変化に対する検出光の感度が高 くなっていることを意味している. 平均実効光路長 $<L>と$ は異なり, 検出光が脳組織内を伝播した距離である部分 実効光路長 $<L_{\text {brain }}>$ を直接測定することは不可能である. したがって, 式(3)に基づいて, 脳組織における吸収変化 を定量的に測定するためには, 頭部組織内の光伝播をシ ミュレーションして脳組織における部分実効光路長を求 める必要がある。

また, 多点計測をおこなって脳機能の断層画像やトポ グラフィー画像を得る場合, 各入射一検出ファイバ対で の減光度がどの部分の脳機能を反映しているかというこ とが，画像の空間分解能を向上させるという観点から重 要となる。ここで, 入射一検出ファイバ対で捉えた減光 度変化が生体組織のどの部分の吸収変化を反映している かという空間感度分布は, 組織内における検出光の伝播 経路の分布と等しくなっている ${ }^{9)}$. X線などの場合, 散乱 の影響はほとんど無視できるため，対象が頭部であって も腕部であっても，X線の伝播経路は照射位置と方向に よって決定されると考えて問題ない. しかし, 光は生体 組織で強い散乱を受けるため, その伝播経路は, 光の照 射位置と方向だけでは決定されず, 生体組織の光学的な 性質によっても変化する. 生体組織内における光の伝播 状態を実測することは不可能であり, 光伝播シミュレー ションをおこなわなければ解析することはできない.

\section{3. 光伝播シミュレーション}

\section{1 光伝播シミュレーションと生体組織の光学的性 質}

生体組織における光伝播をシミュレーションするため に必要な光学的なパラメータには, 散乱係数 $\mu_{s}$, 位相関数 (散乱パターン) $p$, 吸収係数 $\mu_{a}$, 屈折率 $n$ 等がある. 生体組 織の散乱特性は散乱係数と位相関数で決定される。ここ で, 光が多くの散乱を繰り返すような場合には, 等方散 乱近似をおこなって, 位相関数を等方散乱とみなして解 析をおこなうことが可能となる。等方散乱近似をおこ
なったときに用いる散乱係数を等価散乱係数 $\mu_{s}{ }^{\prime}$ という. 生体組織の散乱, 吸収係数を測定する手法には, 組織の サンプルを採取しておこなう積分球法などがある10). 頭 部を構成している各組織の, 波長 $800 \mathrm{~nm}$ の近赤外光に対 する等価散乱係数および吸収係数の一例をTable 1 に示 す11-13)，脳の周囲は，ほとんど散乱がない脳脊髄液で満 たされているため, この領域は他の組織に比べて散乱, 吸収係数が小さくなっている。このことが, 脳組織内の 光伝播に大きく影響を及ぼすことになる8,14).

\section{2 モンテカルロ・シミュレーション15-18)}

モンテカルロ法による生体組織内の光伝播シミュレー ションでは, 光を光子の集まりとして捉え, 組織の光学 的性質と乱数を用いて個々の光子の挙動を推計学的に計 算する。組織内で散乱された光が次に散乱されるまでに 直進する距離 $l$ は, 散乱係数 $\mu_{s}$ と乱数 $R$ を用いて次式で与え られる。

$$
l=-\ln (R) / \mu_{s}
$$

散乱による新たな伝播方向は，位相関数と乱数によって 決定する. 光子が散乱係数の異なる組織を越えて伝播し た場合には, それらの組織の散乱係数を用いて伝播距離 を補正する ${ }^{18)}$. 各光子には, その光子が吸収されずに伝 播を続ける可能性を表す重みが与えられており, 各組織 を光子が伝播した距離とその組織の吸収係数から, 次式 をよって検出光の重みを計算する.

$$
W_{i}=\exp \left[-\sum_{j}\left(\mu_{a, j} l_{i, j}\right)\right]
$$

ここで， $W_{i}$ は $i$ 番目の光子が検出されたときの重みであ る。また，jはモデルを構成している各組織を表してお $\eta, \mu_{a, j}$ は組織 $j$ の吸収係数, $l_{i, j}$ は $i$ 番目の光子が組織 $j$ の中 で伝播した距離を示している。

検出された全光子について重みの平均をとることで検 出光量, 検出された光子の伝播距離と重みの積の平均を とることで平均実効光路長を求めることができる。ま た，検出された光子の伝播経路に重みをつけて加算する ことで，検出光の伝播経路分布すなわち入射一検出ファ イバ対の空間感度分布を求めることができる.

組織の非均質性を考慮したモデルを構築する方法に は, 異なる組織の境界を方程式によって記述する方法 と, 対象を画素や体積素に分割して個々の要素を各組織 に割り当てる方法がある。頭部組織のような複雑な構造 を有する場合, 境界を方程式で記述することは困難であ る. Fig. 1は成人頭部のMRI画像をもとに, 頭皮, 頭蓋 骨, 脳脊髄液, 灰白質, 白質の 5 種の組織からなる頭部モ デルを一辺 $0.5 \mathrm{~mm}$ の正方要素で表したものである。この 成人頭部モデルの各組織に対応する要素にTable 1に示した 散乱，吸収係数を与え，モンテカルロ法を適用すること によって，近赤外光が頭部組織を伝播する状態をシミュ レーションできる。ここで, 脳周囲に存在する散乱の小 さい脳脊髄液層が脳組織内の光伝播に及ぼす影響を示す ため, 脳脊髄液層の部分に頭蓋骨の散乱, 吸収係数を与 


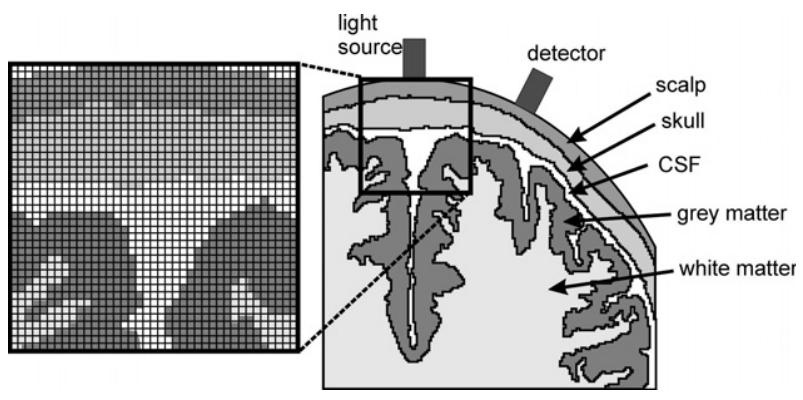

Fig. 1 Adult head model for Monte Carlo simulation.

Table 1 Optical properties of the adult head model.

\begin{tabular}{lcc}
\hline \hline tissue type & $\begin{array}{l}\text { transport scattering } \\
\text { coefficient } \mu_{\mathrm{s}^{\prime}}\left(\mathrm{mm}^{-1}\right)\end{array}$ & $\begin{array}{l}\text { absorption coefficient } \\
\mu_{\mathrm{a}}\left(\mathrm{mm}^{-1}\right)\end{array}$ \\
\hline scalp & 1.9 & 0.018 \\
skull & 1.6 & 0.016 \\
CSF & 0.32 & 0.0048 \\
grey matter & 2.2 & 0.036 \\
white matter & 9.1 & 0.014 \\
\hline \hline
\end{tabular}

えることで脳脊髄液層の影響を無視したモデルについて も, 光伝播シミュレーションを扔こなうこととした. 2つの頭部モデルに対するモンテカルロ・シミュレーショ ンと，4人の被験者の前額部を対象とした時間分解計測に よって実測した平均実効光路長の結果をFig. 2に示す。実 測の結果から, 近赤外光はヒト成人の頭部組織内に扔い て，入射一検出ファイバ対の間隔に対して7〜8倍程度の 距離を伝播していることが分かる。また，脳脊髄液層を 考慮したモデルと考慮しないモデルを比較すると, 脳脊 髄液層を考慮しないモデルでは入射一検出ファイバ対の 間隔に対して平均実効光路長がほほ比例して増加してい るのに対して, 脳脊髄液層を考慮したモデルでは入射一 検出ファイバ対の間隔が $30 \mathrm{~mm}$ を越えるとグラフの傾きが わずかに小さくなる傾向を示している。前額部を対象と した実測の結果は, 脳脊髄液層を考慮したモデルに近い 傾向を示している. 近赤外光を用いた脳機能計測では,

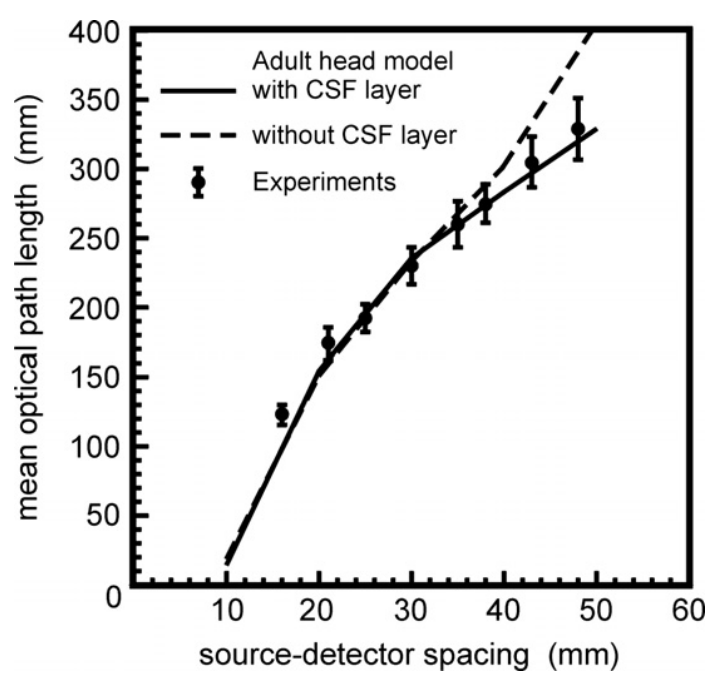

Fig. 2 Mean optical path length as function of source-detector spacing calculated by Monte Carlo method, together with the experimental results.
入射一検出ファイバ対の間隔は $20 \sim 40 \mathrm{~mm}$ 程度に設定され ることが多く，この範囲では平均実効光路長に対する脳 脊髄液層の影響はさほど顕著ではない.

実測で直接求めることが不可能な脳組織内の部分実効 光路長を, $2 つ$ 頭部モデルに対する光伝播シミュレー ションの結果から計算したものがFig. 3である. 脳組織内 に扔ける近赤外光の部分実効光路長は, 入射一検出ファ イバ対の間隔が $30 \mathrm{~mm}$ の場合, 脳脊髄液層を考慮したモデ ルの方が考慮しないモデルに比べて約3倍になっているこ とがわかる。これは, 頭部構造の不均質性, とくに低散 乱層(脳脊髄液)を高散乱層(頭蓋骨と脳組織)で挟んでいる 構造が脳内の光伝播に大きく影響し, 近赤外光による脳 機能計測の感度向上に寄与していることを表している.

つぎに, 光伝播シミュレーションによって得られた検 出光の伝播経路から, 光による脳機能計測の入射一検出 ファイバ間隔と空間感度分布の関係について考える. Fig. 4 は入射一検出ファイバ間隔が $30 \mathrm{~mm}$ と $40 \mathrm{~mm}$ の場合にお ける検出光の伝播経路であり, 図中の等感度線は最大感 度に対して $10^{-1}, 10^{-2}, 10^{-3}$ となる部位を示している. 対象 が均質であると, 検出光の伝播経路は入射一検出ファイ バの中間部分が最も深くなるバナナ形状をとることが知 られている. しかし, Fig.4をみると, 検出光の伝播経路 分布は, 䑈の表面形状に沿うような形状になっているこ とが分かる。 また，この傾向は入射一検出ファイバ対の 間隔が大きくなると，より顕著になっている。このこと は, 低散乱の脳脊䯣液層が脳組織の光伝播に大きく影響 を及ぼしていることを示している。ここで注意しなけれ

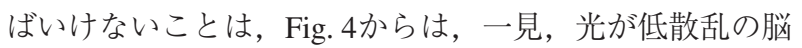
脊髄液内を伝播することで, 脳組織を伝播する光が減少 しているような印象を受ける。しかし，Fig. 3に示したよ うに, 脳脊髄液層が存在することによって, 光が脳組織 内を伝播する距離は増加しており, 近赤外光は脳脊髄液 層を介して頭蓋骨と脳組織の中で拡散反射を繰り返しな がら伝播しているものと考えられる。

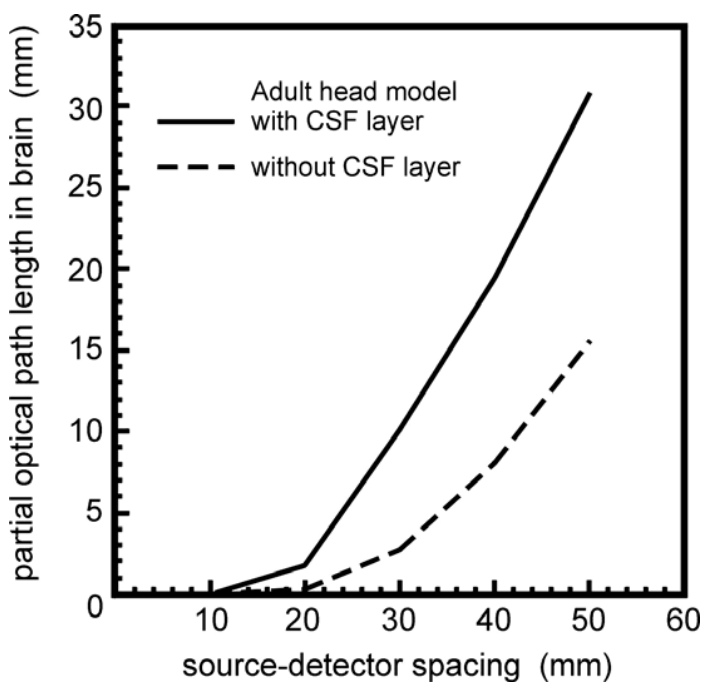

Fig. 3 Partial optical path length in the brain as function of source-detector spacing calculated by Monte Carlo method. 


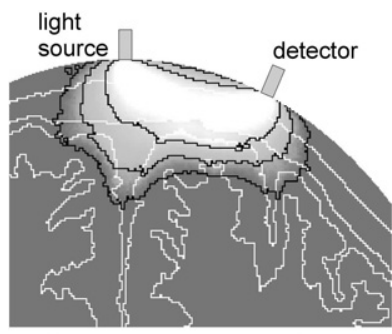

(a) source-detector spacing: $30 \mathrm{~mm}$

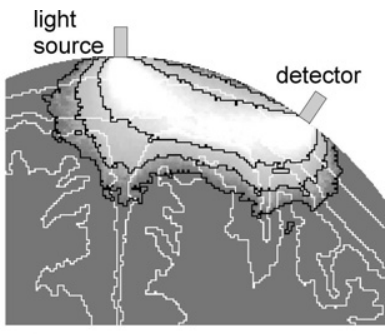

(b) source-detector spacing: $40 \mathrm{~mm}$

Fig. 4 Spatial sensitivity profile in the adult head model at source-detector spacing of (a) $30 \mathrm{~mm}$ and (b) $40 \mathrm{~mm}$ calculated by Monte Carlo method.

3.3 光拡散方程式とモンテカルロ・シミュレーショ ンのハイブリッド法

モンテカルロ法は, 比較的簡単なアルゴリズムで生体 組織内の光伝播を正確にシミュレーションできるという 特長があるが, 解が統計的に安定するまでに多くの演算 時間を要するという久点がある。一方，生体組織のよう な高散乱媒質内の光伝播は, 式(6) に示した光拡散方程式 によって記述することが可能である。

$-\nabla \cdot \kappa \nabla \Phi+\mu_{a} \Phi=q_{0}$

ここで, $\Phi$ は光子密度, $\kappa$ は拡散係数 $\left(\kappa=1 /\left(3 \mu_{s}^{\prime}\right)\right), q_{0}$ は 光源を表している. 光拡散方程式を解析的22) または数值 的23)に解くことによって生体モデル内の光伝播をシミュ レーションすることができるが，頭部のような複雑な形 状の非均質構造を持った対象を解析する場合には，有限 要素法によって数值解を求める方法が有効である。しか し, 光拡散方程式は, 散乱係数が高く, 光が等方的に拡 散しながら伝播するとみなせる領域にしか適用すること ができない，つまり，頭部組織の光伝播をシミュレー ションする場合, 低散乱の脳脊髄液層については, 光拡 散方程式を適用しても正確な光伝播を求めることはでき ない。また，脳組織内の光伝播をシミュレーションする さいに, 脳脊髄液層の存在を無視できないことは, 前節 で述べた通りである。

そこで, 高速かつ正確に脳内の光伝播をシミュレー ションする方法として光拡散方程式とモンテカルロ・シ ミュレーションを組み合わせたハイブリッド法が提案さ れている19-21)。これは, 頭部モデルに扔いて, 光拡散方程 式が成立する表層部(頭皮, 頭蓋骨) および脳組織の光伝播 のシミュレーションには光拡散方程式を用い, 光拡散方 程式が成立しない脳脊髄液層の光伝播はモンテカルロ法 によって解析を扔こなうという方法である。

Fig. 5は頭部の構造を多層平板に簡単化したモデルであ り，このモデルを用いてハイブリッド法による光伝播シ ミュレーションを説明する。このモデルにおける上層の 平板は頭皮と頭蓋骨，下層の平板は脳組織を模擬してい る.これらの領域は光拡散方程式で光伝播がシミュレー ションできることから, 有限要素法を適用するために三 角形の要素で構成されている，2枚の平板に挟まれた脳脊 髄液層では光拡散方程式が成立しないため，この部分の 光伝播はモンテカルロ法で計算する。このとき, 脳脊䯣

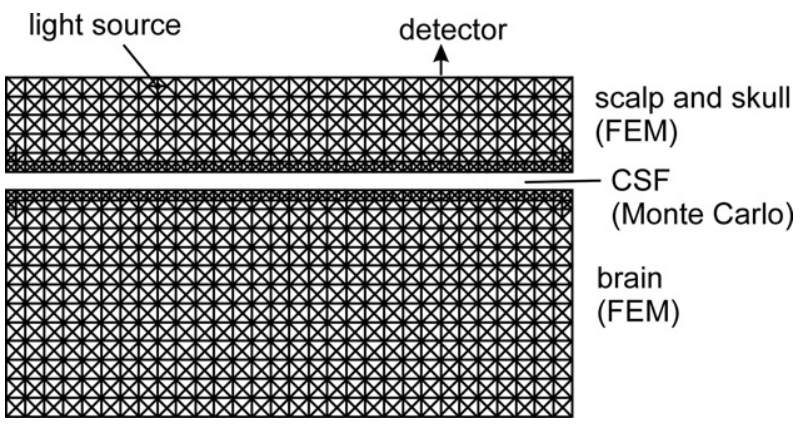

Fig. 5 Head model for hybrid Monte Carlo-diffusion method.

液層内の光伝播を考えると, Fig. 6に示したように，頭蓋 骨表面のある要素 $q$ から放射された光は, 脳脊䯣液層で散 乱されて, 脳組織側の各要素と頭蓋骨側の各要素へと到 達する。このことは，脳組織表面のある要素から放射さ れた光についても同様である。そこで，一つの要素から 放射された光が, 脳脊髄液層に接する個々の要素に伝播 する割合を表す係数を，あらかじめモンテカルロ法に よって計算して打く，脳脊髄液層からある要素に入射す る光強度は, 頭蓋骨表面と脳組織表面の各要素から放射 される光にモンテカルロ法で計算した係数を掛けて, 積 分することによって計算することができる，具体的な計 算手順としては，まず，入射光による上層の光伝播を有 限要素法で計算し, 頭蓋骨の各要素から脳脊髄液層に向 かって放射される光量を求める. この光量とモンテカル 口法で求めた係数を用いて, 脳脊髄液内を伝播して脳表 面の各要素に到達する光量と頭蓋骨の各要素に反射する 光量を求める. 脳表面の各要素に到達した光量を光源に 置き換えて, 下層の光伝播を有限要素法で計算し, 脳表 面の各要素から脳脊髄液層に向かって放射される光量を 求める. 再びモンテカルロ法で求めた係数を用いて, 頭 蓋骨の各要素へ伝播する光量と脳組織の各要素へ反射す る光量を求める。ここで, 脳春䯣液層側から頭蓋骨の各 要素に到達した光量を光源に置き換えて, 上層の光伝播 を有限要素法で再計算する。このような計算を結果が収 束するまで繰り返すことで, 頭部モデルの光伝播がシ ミュレーションできる.

Fig. 5に示した頭部モデルに対して, 頭皮と頭蓋骨を表 す上層の等価散乱係数を $1.75 \mathrm{~mm}^{-1}$, 吸収係数を 0.017 $\mathrm{mm}^{-1}$, 脳組織の等価散乱係数を $2.2 \mathrm{~mm}^{-1}$, 吸収係数を

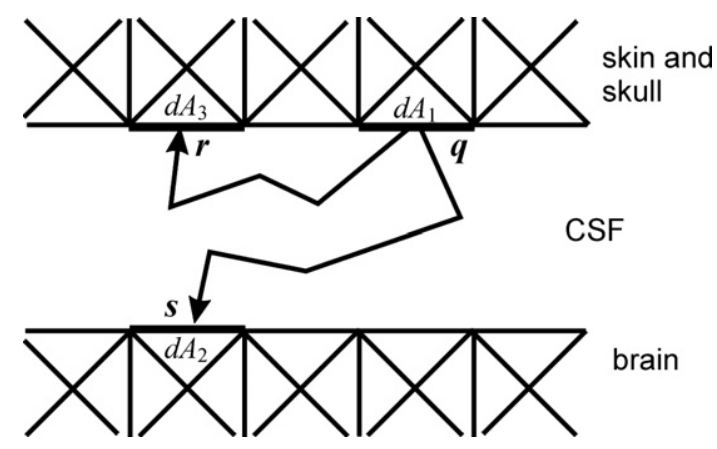

Fig. 6 Monte Carlo calculation of contribution of flux from skull to each element on the surface of brain and skull. 
$0.036 \mathrm{~mm}^{-1}$, モンテカルロ法で計算をおこなう脳脊髄液層 の等価散乱係数を $0.3 \mathrm{~mm}^{-1}$, 吸収係数を $0.002 \mathrm{~mm}^{-1}$ とし て, 検出光の平均実効光路長をハイブリッド法とモンテ カルロ法で計算した結果をFig. 7に示す. ハイブリッド法 とモンテカルロ法の結果はよく一致しており，ハイブ リッド法によって頭部組織内の光伝播シミュレーション が正確におこなわれていることがわかる。ここで, Pentium II 450MHzのCPUを用いた場合で両者の計算時間 を比較すると, モンテカルロ法で5×107個の光子について 計算をおこなうために約 300 時間を必要としたのに対し て，ハイブリッド法では約 300 秒で計算をおこなうことが 可能であった。これは，ハイブリッド法においてモンテ カルロ・シミュレーションで計算をおこなう必要がある 脳脊髄液層は面積が小さいため短時間で計算が収束する ことと, 繰り返し演算をおこなうのが有限要素法を用い る部分だけであることに起因している. ハイブリッド法 を用いた場合でも, Fig. 8に示したように検出光の伝播経 路を算出することができる. 平板モデルであるため, Fig. 4と比べると脳脊髄液層が光伝播に及ぼす影響はさほど顕 著ではないが, 脳脊髄液層近傍で等感度線が外側に歪ん でいる様子が分かる。

ここでは，ハイブリッド法を適用する頭部モデルとし て形状が簡単な多層平板モデルを用いたが, 有限要素法 は比較的自由に形状を設定できるため, Fig. 1に示したよ うな実際の頭部構造に近いモデルを構築することも可能 である。ただし, この場合, 脳脊髄液層の形状も複雑に なるため，モンテカルロ法による係数計算にはより多く の時間が必要になるものと考えられる。しかし, 一旦係 数が求まれば, 有限要素法を用いる繰り返し演算に要す る時間はモデルの形状にはほとんど依存しない.

\section{4. まとめ}

近赤外光を用いた脳機能計測における光伝播シミュ レーションの必要性と, モンテカルロ法とハイブリッド 法によるシミュレーション例について紹介した．光によ

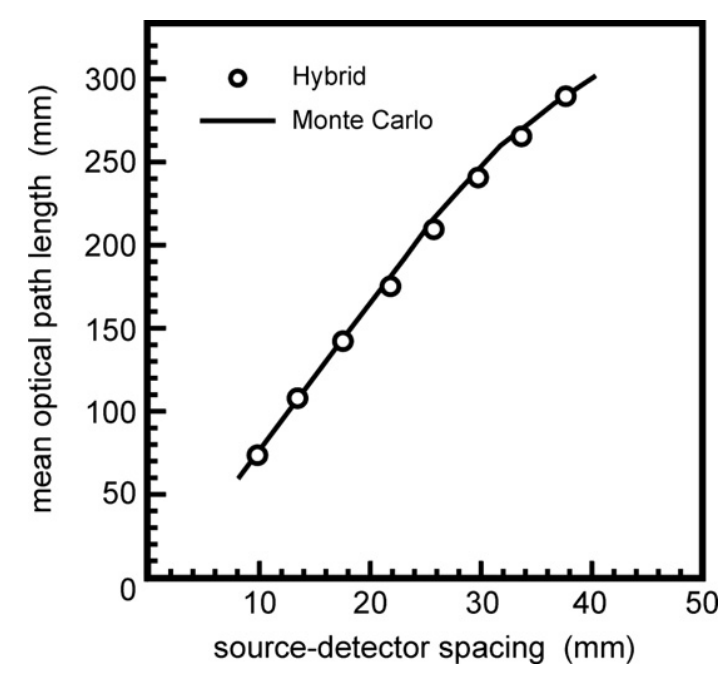

Fig. 7 Mean optical path length calculated by hybrid Monte Carlo-diffusion method.
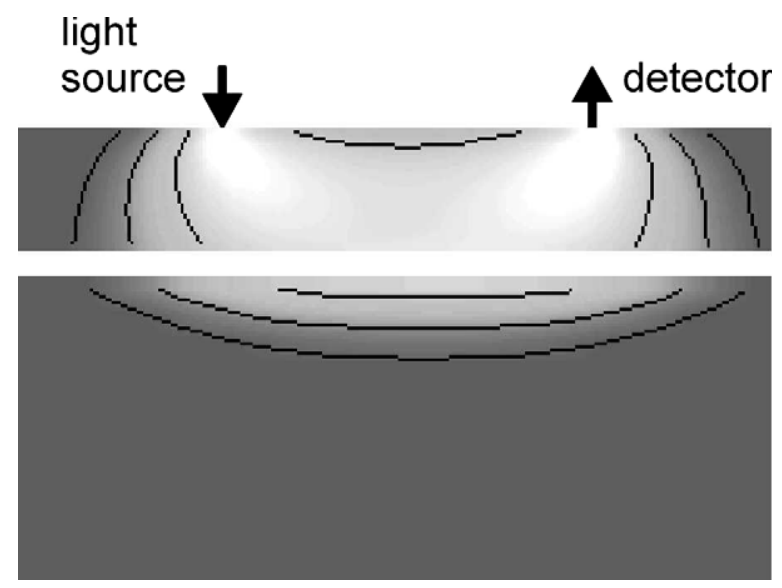

Fig. 8 Spatial sensitivity profile in the head model at sourcedetector spacing of $30 \mathrm{~mm}$ calculated by hybrid Monte Carlo-diffusion method.

る脳機能計測は, 単に測定に成功したという段階を終え て, 精度, 信頼性の高い測定, 空間分解能の高い脳機能 画像の取得という観点から研究が進められるようになっ てきている．頭部組織の非均質性は脳組織内の光伝播に 大きく影響を及ぼしていることから，光による脳機能計 測における脳内の光伝播シミュレーションの重要性は, 今後ますます高まるものと考えられる。生体組織の光伝 播シミュレーションは, 対象となる組織の解剖学的構造 と, 散乱係数, 吸収係数に代表される組織の光学的パラ メータに基づいて計算がおこなわれる。したがって, 正 確な形状データと光学的パラメータを用いることが精度 の高い光伝播シミュレーションの前提条件となる. 形状 に関してはMRIなどによって正確なデータを取得すること が可能である. 一方, 種々の生体組織の散乱, 吸収係数 に関する知見は現在のところ必ずしも十分でなく，また その多くは生体活性を失ったサンプルを対象に測定した ものである。より精度の高い光伝播シミュレーションを おこなうためには, 生体組織の光学的パラメー夕に関す る知見の蓄積と, 生体組織を採取せずに生体活性を保っ たままで散乱，吸収係数を測定する技術の確立が重要で あると考えられる。

\section{謝 辞}

時間分解計測によるヒト前額部の平均実効光路長測定 は, 慶應義塾大学理工学部電子工学科神成文彦教授の研 究グループの協力によっておこなったものである。ここ に記して謝意を表する。

\section{参考文献}

1) H. Eda, I. Oda, Y. Ito, Y. Wada, Y. Oikawa, Y. Tsunazawa, M. Takada, Y. Tsuchiya, Y. Yamashita, M. Oda, A. Sassaroli, Y. Yamada, and M. Tamura: Rev. Sci. Instrum. 70 (1999) 3595.

2) F. E. W. Schmidt, M. E. Fry, E. M. C. Hillman, J. C. Hebden, and D. T. Delpy: Rev. Sci. Instrum. 71 (2000) 256.

3) H. Dehghani, E. M. C. Hillman, M. Schweiger, S. R. Arridge, and D. T. Delpy: Proc. SPIE 4250 (2001) 45.

4) A. Maki, Y. Yamashita, Y. Ito, E. Watanabe, Y. Mayanagi, and H. 
Koizumi: Med. Phys. 22 (1995) 1997.

5) H. Koizumi, Y. Yamashita, A. Maki, T. Yamamoto, Y. Ito, H. Itagaki, and R. Kennan: J. Biomed. Opt. 4 (1999) 403.

6) D. T. Delpy, M. Cope, P. van der Zee, S. Arridge, S. Wray, and J. Wyatt: Phys. Med. Biol. 33 (1988) 1433.

7) M. Hiraoka, M. Firbank, M. Essenpreis, M. Cope, S. R. Arridge, P. van der Zee, and D. T. Delpy: Phys. Med. Biol. 38 (1993) 1859.

8) E. Okada, M. Firbank, M. Schweiger, S. R. Arridge, M. Cope, and D. T. Delpy: Appl. Opt. 36 (1997) 21.

9) E. Okada, M. Firbank, and D. T. Delpy: Phys. Med. Biol. 40 (1995) 2093.

10) J. W. Pickering, S. A. Prahl, N. van Wieringen, J. F. Beek, H. J. C. M. Sterenborg, and M. J. C. van Gemert: Appl. Opt. 32 (1993) 399.

11) C. R. Simpson, M. Kohl, M. Essenpreis, and M. Cope: Phys. Med. Biol. 43 (1998) 2465.

12) M. Firbank, M. Hiraoka, M. Essenpreis, and D. T. Delpy: Phys. Med. Biol. 38 (1993) 503.

13) P. van der Zee, M. Essenpreis, and D. T. Delpy: Proc. SPIE 1888
(1993) 454

15) L. Wang, S. L. Jacques, and L. Zheng: Comput. Method and Programs in Biomed. 47 (1995) 131.

14) E. Okada and D. T. Delpy: Proc. SPIE 4160 (2000) 196.

16) S. T. Flock, M. S. Patterson, B. C. Wilson, and D. R. Wyman: IEEE Trans. Biomed. Eng. 36 (1989) 1162.

17) S. Eda and E. Okada: Proc. SPIE 4250 (2001) 383.

18）江田周平, 岡田 英史：電子情報通信学会論文誌D-II, J84-DII (2001) 2654.

19) M. Firbank, S. R. Arridge, M. Schweiger, and D. T. Delpy: Phys. Med. Biol. 41 (1996) 767.

20) Y. Kashio, M. Ono, M. Firbank, M. Schweiger, S. R. Arridge, and E. Okada: Proc. SPIE 4160 (2000) 83.

21) T. Hayashi, Y. Kashio, and E. Okada: Proc. SPIE 4431 (2001) 169

22) M. S. Patterson, B. Chance, and B. C. Wilson: Appl. Opt. 28 (1989) 2331.

23) S. R. Arridge, M. Schweiger, M. Hiraoka, and D. T. Delpy: Med. Phys. 20 (1993) 299.

\section{モンテカルロ・シミュレーション}

\section{(Monte Carlo simulation)}

モンテカルロ・シミュレーションは，乱数を利用して 行う計算機シミュレーションの総称であり，その適用範 囲は様々な物理現象の解析から金融工学まで, 非常に広 い分野に及んでいる。モンテカルロ・シミュレーション の特長は，確率的に事象を取り扱うことで，決定論的な 解析をすることが困難な対象についても比較的簡単，か つ直感的にシミュレーションが行える点にある. 反面,
大規模なシミュレーションでは, 解析結果が統計的に安 定するまで膨大な計算時間を要することが問題となる。 散乱系における光伝播のモンテカルロ・シミュレーショ ンは, 光を光子の集合として捉え, 乱数と光学的パラ メー夕を用いて，個々の光子が散乱されるまで直進する 距離や散乱されたときの新たな伝播方向を計算すること によって，光伝播解析を行うものである。（岡田英史) 